\title{
関東平野における地下水の年代測定とその水文地質学的研究
}

\author{
落 合 敏 郎*

\section{Groundwater Hydrology in Kanto Plain by the Use of Tritium Dating} \\ Toshiro OCHIAI
}

\begin{abstract}
The utilization of natural tritium plays the most important role in surveying large areas for the development of groundwater resources.

The flow velocity and flow distribution of the groundwater in a large water system could not be directly calculated by other methods in the past.

In the study reported here, bomb-produced tritium was used as a tracer to estimate mean groundwater velocities by the distance of seepage from the groundwater recharge zone.

At present, the concentration of natural tritium is obtained by the following: 101 -groundwater in the deep layer intercepted from the shallow water by clay layer is concentrated into one-hundreds $\mathrm{ml}$ by 2 -step electrolysis after distillation; its tritium concentration is measured by the liquid scintillation spectrometer.

The tritium unit (T.U.) of the groundwater in the Kanto plain showed 2 to $406 \mathrm{~T}$. U.

Natural tritium content of levels is less than $5 \mathrm{~T}$. U. Therefore, the 1954 front are estimated to have moved $40 \mathrm{~km}$ along the basin of the River Tone and $48 \mathrm{~km}$ along the basin of the River Kinu. The groundwater velocities were computed $9 \mathrm{~m} / \mathrm{d}$ and $11 \mathrm{~m} / \mathrm{d}$ respectively. It was clarified that the deep groundwater in the Kanto Plain is strongly followed by the geological structure of the Kanto structural basin and flow out towards the Tokyo Bay according to the past results.
\end{abstract}

\section{1.はしがき}

最近，広域における地下水のかん養分布，流動速度を明らかにする方法として，天然 Tritium に よる年代決定が重要視され，諸外国においてもその研究が盛んに行なわれているいー4。

Tritium $\left({ }^{3} \mathrm{H}\right)$ は最大 $18 \mathrm{KeV}$ の $\beta$ 線を出して半減期 12.5 年で ${ }^{3} \mathrm{He}$ となるが, この核種は宇宙線に よって成層圏で常時生成されており，1954 年以来の水爆実験の以前においても $1 \sim 10 \mathrm{~T} . \mathrm{U}$. 程度の微 量のTritiumが雨水に含まれていたことが知られている。1954年以降の水爆実験によって，Tritium 濃度は指数的に増大し, 10 から 1,000 T.U. という異常に高い值を示すに至った。したがって，地下 水を採水して Tritium 濃度を測定すれば, 1954 年の水爆実験以前・以後の地下水年代の区分，およ び水爆実験以前であれば地下水生成後の経過年数を明らかにすることができる。すなわち，天然・水 爆 Tritium の測定から地下水の年令を求めることができるわけである。

したがって，地下水の年令を知れば， large-scale の水文学のなかで地下水のかん養分布，速度を 明らかにすることが可能となる。

筆者は1964年からこの研究を進め, 土地改良第 2 研究室員木村・朝倉・川崎の諸氏の協力を得て, 関東地方の代表的地点16か所の深層地下水の年代を 3 か年にわたって求めた。

本報文はこれらの測定結果をもとにして, 関東水系の地下水の流動機構, 地下水流速について水文 地質学的検討を行なった結果について述べている。

なお，この研究の実施にあたっては, 科学技術庁・研究調整局, 科学研究所・放射線利用研究室浜 田・高橋らの諸氏に多大の御支援と御便宣とをいただいた。ここに厚く感謝の意を表する次第である。 


\section{Tritium による地下水の年代測定法}

Tritium は水素の isotope であり，その化学的・物理的特性は水素に等しい。したがって normal water $[\mathrm{HOH}]$ と tritiated water $(\mathrm{TOH})$ とは非常によく似ている。したがって, tritiated water 㴖水層中で normal water と同じ行動をとるので, 地下水の tracer として理想的元素と考兄られ る。

Tritium による地下水の年代决定においては Tritium 濃度が非常に薄く， 1 T.U. 程度のものを 測定する必要があり，その上，Tritium の $\beta$ 線エネルギーが非常に弱いので，まず，濃縮を行ない， 濃縮後の試料の測定を低レベル用水素充填計数管で試料水を $\mathrm{H}_{2}$ ガスの還元状態で測定するか, 液体 シンチレーション・カウンタを用いて tritiated water の液体の形で測定する方法がとられている。 筆者は後者の液体シンチレーションによる測定法を用いた。

Tritium は自然に大気中の ${ }^{14} \mathrm{~N}$ と宇宙線のなかの高速中性子とが ${ }^{14} \mathrm{~N}(\mathrm{n}, \mathrm{t}){ }^{12} \mathrm{C}$ という核反応を 起こし，大気中に生成される。天然 Tritium の生成率嗵去より一定とされ，地球表面に打いて常 時 1 秒間 $1 \mathrm{~cm}^{3}$ 中に 1 コの割合であるとされている。このようにして生成された天然の Tritium 濃 度は 1〜10 T.U. とされている。これが凝縮して雨水の降下とともに地表に落ち, 地下に浸透して地 下水となる。したがって，この天然の Tritium が地下にもぐると，12.5 年の半減期で減衰するから， 浅層水の浸透による混入が生じない限り減衰から地下水の年代を求めることが出来る。るし，50年経 過すると, 10 T.U. のレベルのものは

$N_{t}=N_{o} e^{-0.693 t / T}$ （ただし， $T$ : 半減期， $t:$ 経過時間， $N_{o}: t=0$ における放射性核種の量， $N_{t}$ : 㭙

刻 $t$ における放射性核種の量)

から 0.6 T.U. となり，6\%の Tritium が残ることになる。この值は Tritium の測定限界ライ ンとなる。したがって，Tritium による年代測定の Time scale は約50年ということができる。こ の天然レベルの Tritium は, 1952 年とくに 1954 年以降の水爆実験によって人工の Tritium が全世 界に拡散し，降水中の Tritium 濃度が著しく増大した。図 1 はこれまでに発表された降水，ブドウ

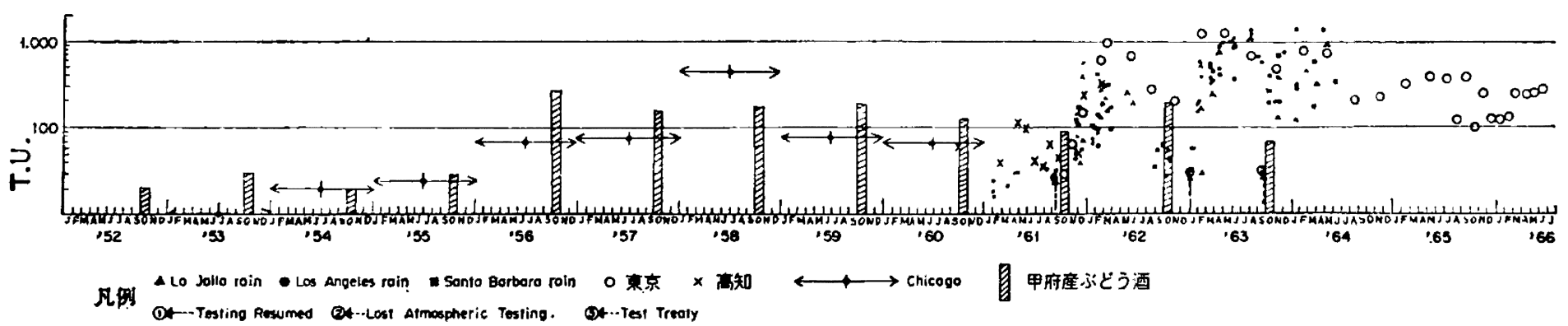

図 1

酒中の Tritium 濃度の資料を筆者が調整し同一図にまとめたものである。アメリカにおける1953年 以降の降水中の Tritium 濃度は, 水爆実験以後の Tritium 濃度の増大がいかに大きいかがわかる。 次に太平洋諸島と東京の降水中の Tritium 濃度とを比較すると, 極めて高い相関性を示している。 また, 甲府産のブドウ酒)に 1954 年の水爆実験を境として Tritium 濃度が増大している。わが国に おいては水爆直後の降水の観測データーがないけれぞも，これらのデータから1954年以降の降水中の Tritium 濃度は, 宇宙線によって生成された Tritium 濃度 (1〜10 T. U.) に比較して数倍以上の值 であったことは間違いない。污染直前の天然レベルの Tritium 濃度は, 1954 年の水爆実験から約 12 年を経過しているので，その濃度は 0.5 5 T. U. となる。したがって, 1954 年の水爆実験以後の降

註）T.U.は Tritium Unit の略でTritium の含有量の単位としてょく用いられる。.1T.U.は Tritium 原子数と水素原子数の比, ${ }^{3} \mathrm{H} /{ }^{1} \mathrm{H}$ が $1 \times 10^{-18}$ であることを示す。 $1 \mathrm{~T} . \mathrm{U} .=3.2 \times 10^{-15} \mathrm{c} / \mathrm{mlH}_{2} \mathrm{O}$ である。 


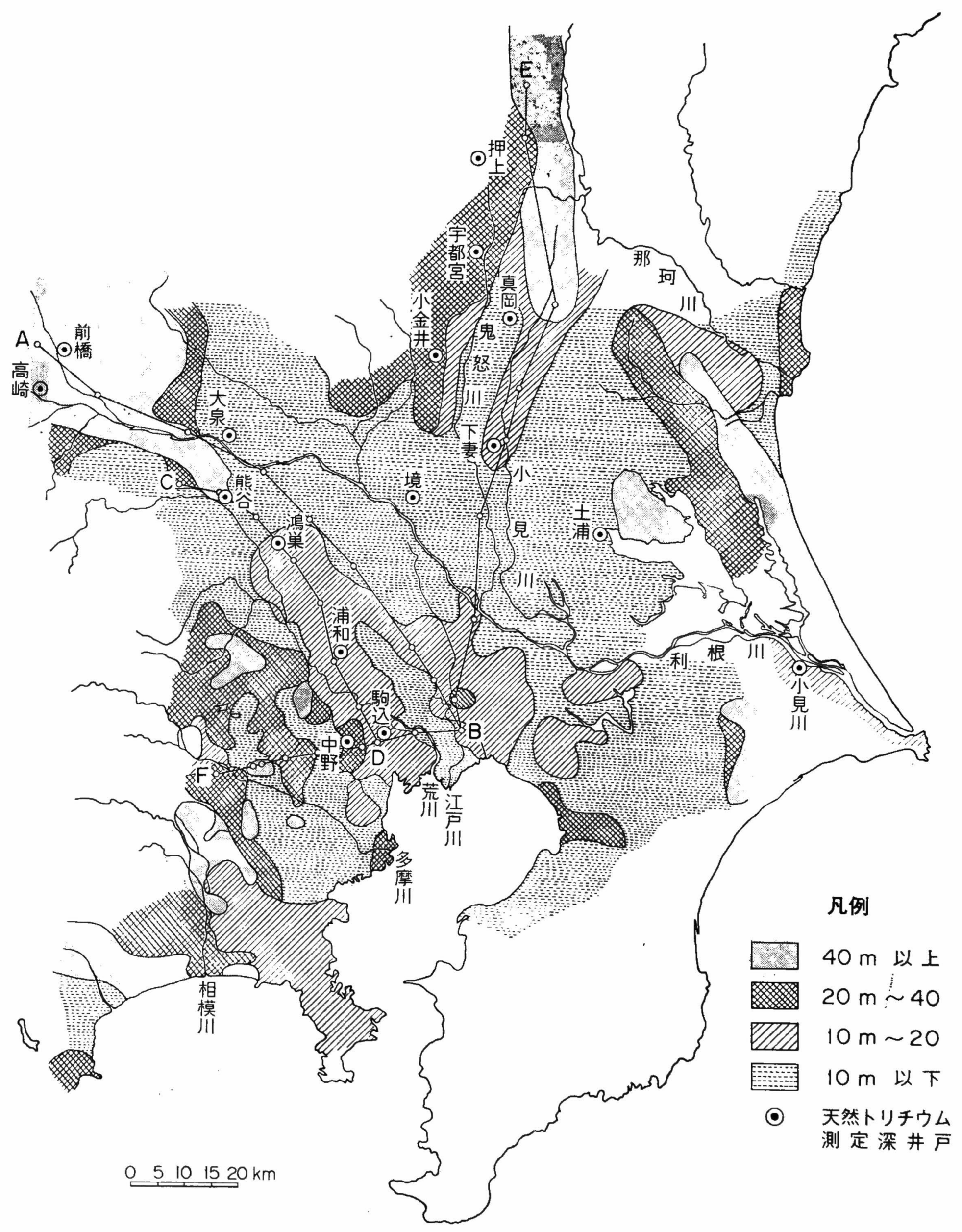

図 2 関東平野の第一不透水盤の深度分布図 
水の増大した Tritium 濃度は, 当然これ以上の值を示すことになる。したがって, 自由地下水と遮 断されている深層地下水を採水して 5 T. U. 以下であれば， 1954 年以前の降水であり，それ以上にな れば 1954 年以後の新しい地下水と判定できる。

a. 地下水試料の採水

深層地下水の年代を決定し，これから深部の地下水の流動機構を究明するためには，最近の水爆実 験による天然 Tritium 濃度の高い雨水が垂直浸透をして直接収水層に達するような水理地質構造を 持つ深井戸では不適当であって，少なくとも浅層部において厚さ $20 \sim 30 \mathrm{~m}$ 以上の広範囲に，かつ連 続的に分布する粘土層があって，雨水の直接的な浸透を遮断している深井戸を選定しなければならな い。この選定のために, 関東地方の深井戸地質柱状図 631 本を収集し, 自由地下水面の第 1 不透水層 梁度分布図と透水俰数分布図とを作成した。(図 2 ・困 3 )

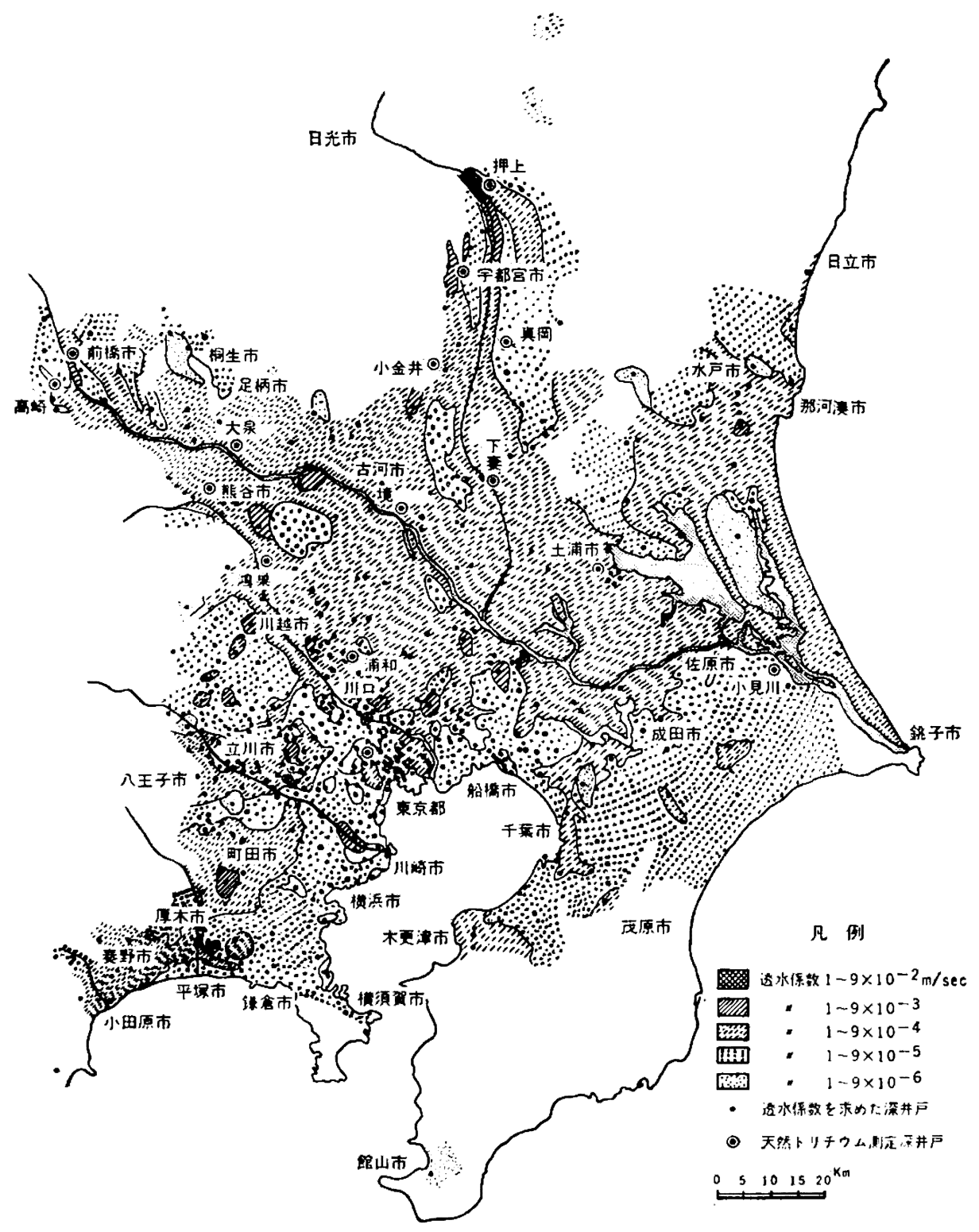

図 3 関東平野の透水係数分布図

これから利根川・鬼怒川上流の地下水が伏没するかん養地帯，およびその伏没した地下水が中・下 流域の不透水層によって被圧化される地帯を推定し, Tritiumの測定によって地下水のかん養区域, 地下水流速が求められるように水文地質学的検討を行ない, 深井戸水の採水を三浦層群中のもの 1 本, 洪積層の砂レキ層のもの 5 本, 沖積下部層中のもの10本とした。その位置を図 4 に示した。 


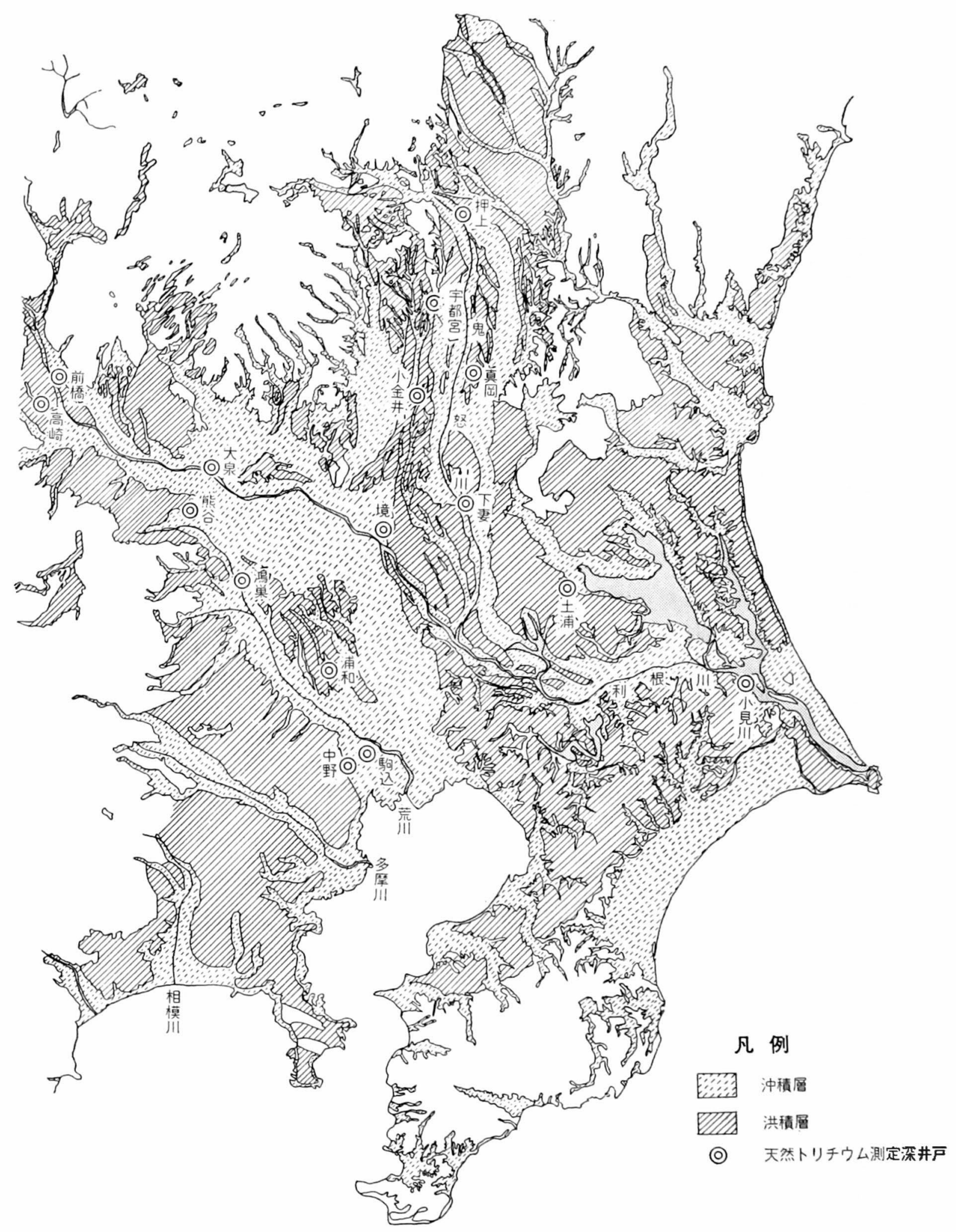

図 4 Tritium 測定の深井戸位置図

\section{b. 採水試料の電解濃縮}

液体シンチレーションカウンタの Tritium 濃度の検出限界は, Tritium 水量 $3.3 \mathrm{ml}$, 計数効率 $10 \%$, 最低有効計数をバックグラウンド $10 \mathrm{cpm}$ の平方根, $100 \mathrm{~T}$. U. を $0.72 \mathrm{dpm} \mathrm{H} / \mathrm{ml}$ 水とする と, $\frac{\sqrt{10}}{3.3 \times 0.10} \times \frac{100}{0.72} \doteqdot 1300$ T. U. の通り 1300 T. U. となる。前述したように採水試料の天然レべ ルの Tritium 濃度は 10 T. U. 以下と考元れるから, 液体シンチレーションカウンタで測定する には採水試料を約 $1 / 100$ 以上に濃縮しなければならない。 
鉄電解槽 15 本によって，それぞれ $1 l$ の試料水を $1 / 10$ に濃縮し，図 6 の第二段のガラス電解槽() 10 本を用いてその液を更に $1 / 10$ に濃縮した。その場合, 試料水重量の $0.8 \%$ に相当する $\mathrm{NaOH}$ を加え て溶解し, 電極面積当り $0.05 \mathrm{~A} / \mathrm{cm}^{2}$ の電流で電解した。この際, 濃縮度をできるだけ一定に保ち,

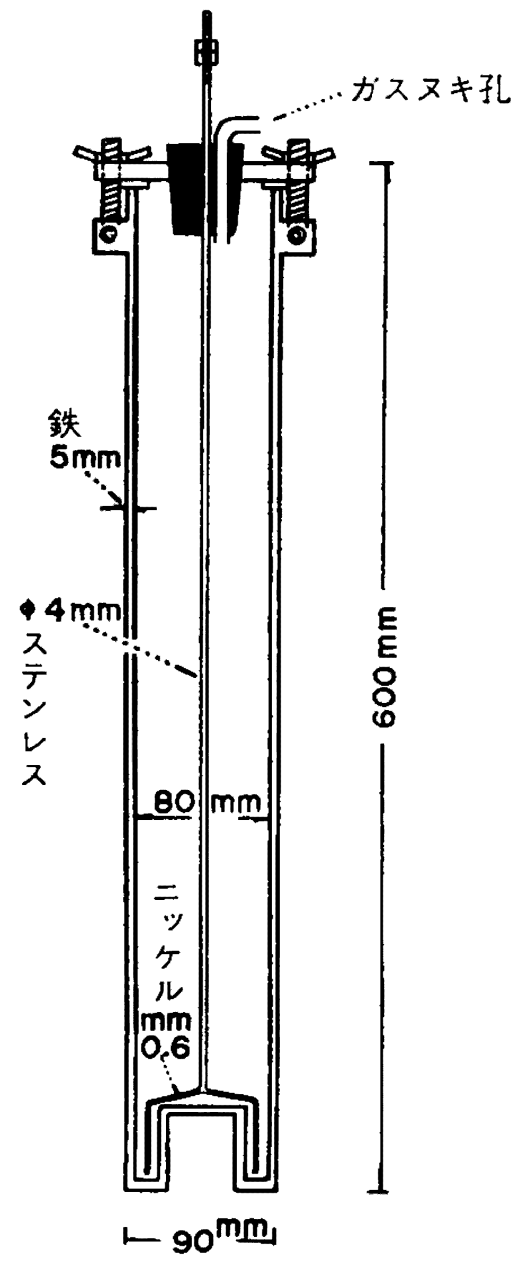

図 5 大型電解槽
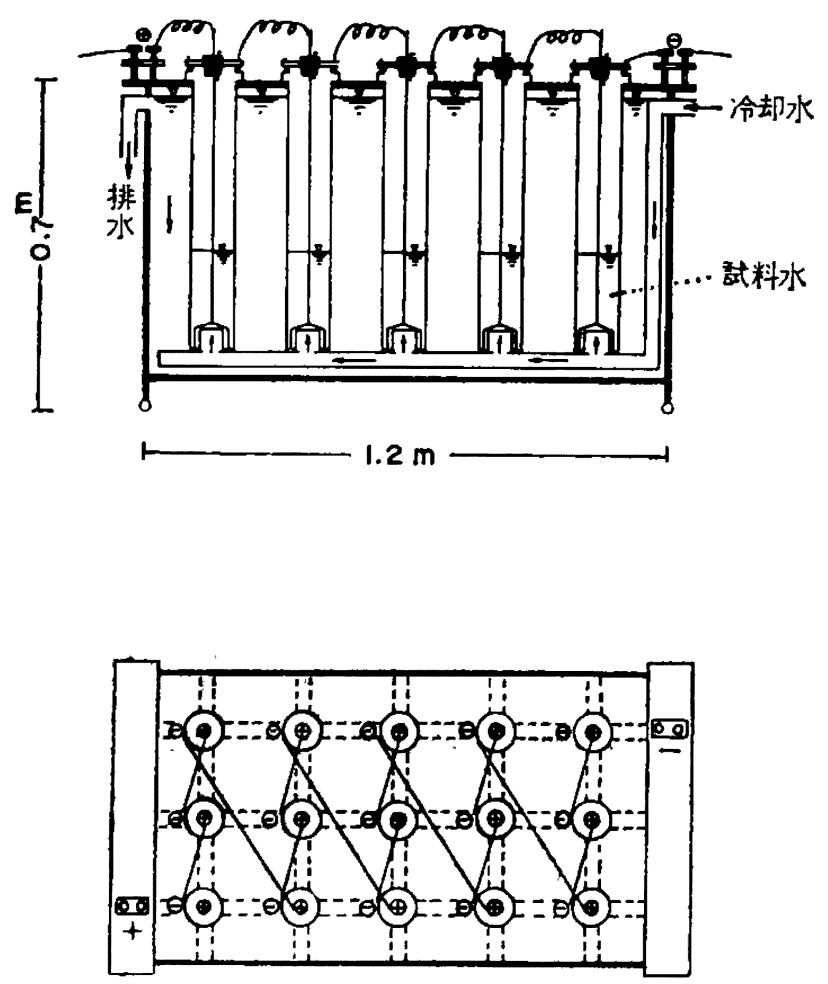

図 7 大型電解槽を収容した恒温水槽

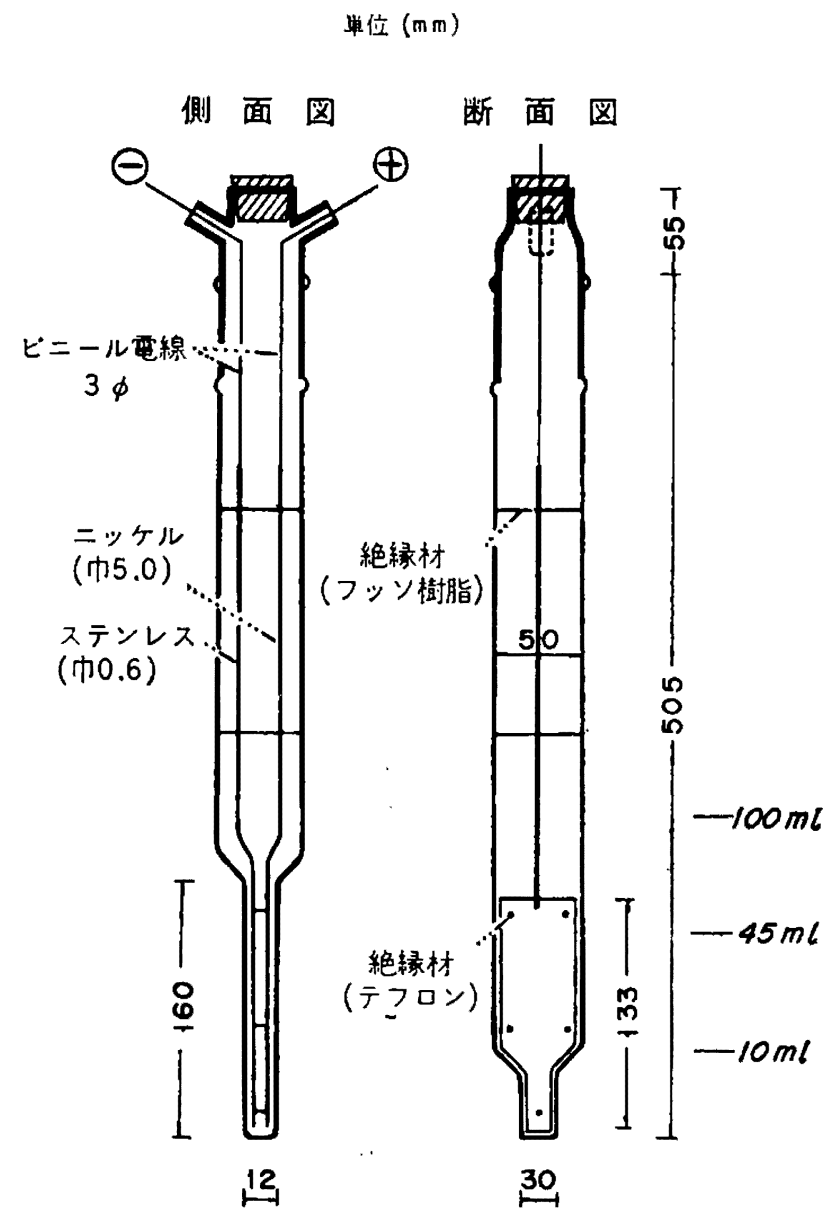

図 6 ガラス電解槽

蒸発による損失や電極の腐蝕を防ぐため,これらの 電解槽を一定温度に冷却した図 7 の恒温水槽に浸し， 連続的に約 20 㡺夜電解した。試料は電解終了後, 溶 液に炭酸ガスを約 15 分加元て液中の $\mathrm{NaOH}$ を炭酸 ソーダの形とした後に蒸溜した。

電解濃縮された試料水中の Tritium 濃度は濃縮 比と一次に比例せず次の関係で濃縮される。

$$
\frac{V}{V_{0}}=\left(\frac{d V}{d_{0} V_{0}}\right)^{\alpha}=\left(\frac{t V}{t_{0} V_{0}}\right)^{\beta}
$$

ここに $V_{0}, V$ はそれぞれ電解前後の試料水量, $d_{0}, d$ 以電解前後の重水濃度, $t_{0}, t$ は電解前後の Tritium 濃度， $\alpha, \beta$ はそれぞれ重水と Tritium.と の分離定数 (Separation factor) である。したがっ $\tau$, Tritium の濃縮度を求めるには重水とTritium 濃度の電解前後の既知の試料によってあらかじめ各 
電極ごとに異なる $\alpha, \beta$ を明らかにしておき，次に測定資料ごとに $d$ と $d_{0}$ の值を求める必要があ る。 $\beta / \alpha$ 值は鉄一ニッケル電極容器が $6.02 / 4.09=1.47$ ，ガラス電極容器が $5.05 / 2.58=1.96$ となっ た。

重水の初期濃度 $d_{0}$ は, 高橋旦の見解にしたがって $0.0155 \%$ と仮定し, 電解終了時の重水濃度 $d$ は昭和電工に測定を依頼した。

c. 液体シンチレーションカウンタによる Tritium 濃度の測定

測定法は tritiated water をそのまま液体シンチレータに溶かす方法をとった。

使用した計数装置は Packard 社製の Tri-Cub, 液体シンチレーションカウンタ Model 3,000で, 光電管は EMI の $9514 \mathrm{~S}$ を 2 本使用してある。2 channel の Window を持ち，試料 200 個が自動 的に自記記録できる。測定部は freezer によって定温に保つ。

シンチレータは Figure of Merritのよいppo $6 \mathrm{~g} / l$, popop $0.3 \mathrm{~g} / l$, ナフタレン $120 \mathrm{~g} / l$, (測定 温度 $5^{\circ} \mathrm{C}$ ）のカクテルの処法によった。測定時間は 100 分間の 4 回で繰返し測定とした。

\section{3. 関東の地下水年代とその水文地質学的解积}

表 1 に Tritium 濃度から算出した T. U. 值を示した。これらの Tritium 濃度をみると，とくに 季別的な傾向はみられず，むしろ地域別によって Tritium 濃度が変化している。

以下 Tritium の測定結果を水文地質学的に検討する。前橋・高崎の利根川上流地帯, 押上の鬼怒 川上流地带，熊谷の荒川上流地帯などで，20３69 T.U.の強いTritium 濃度が検出されたのは，最 近の100 500 T.U. の Tritium 濃度をもつ降水が直接的に透水性の厚い堆積層を浸透した結果によ るものと思われ，きわめて新しい地下水と判定される。図 3 の透水係数分布図によれば，上記の地帯

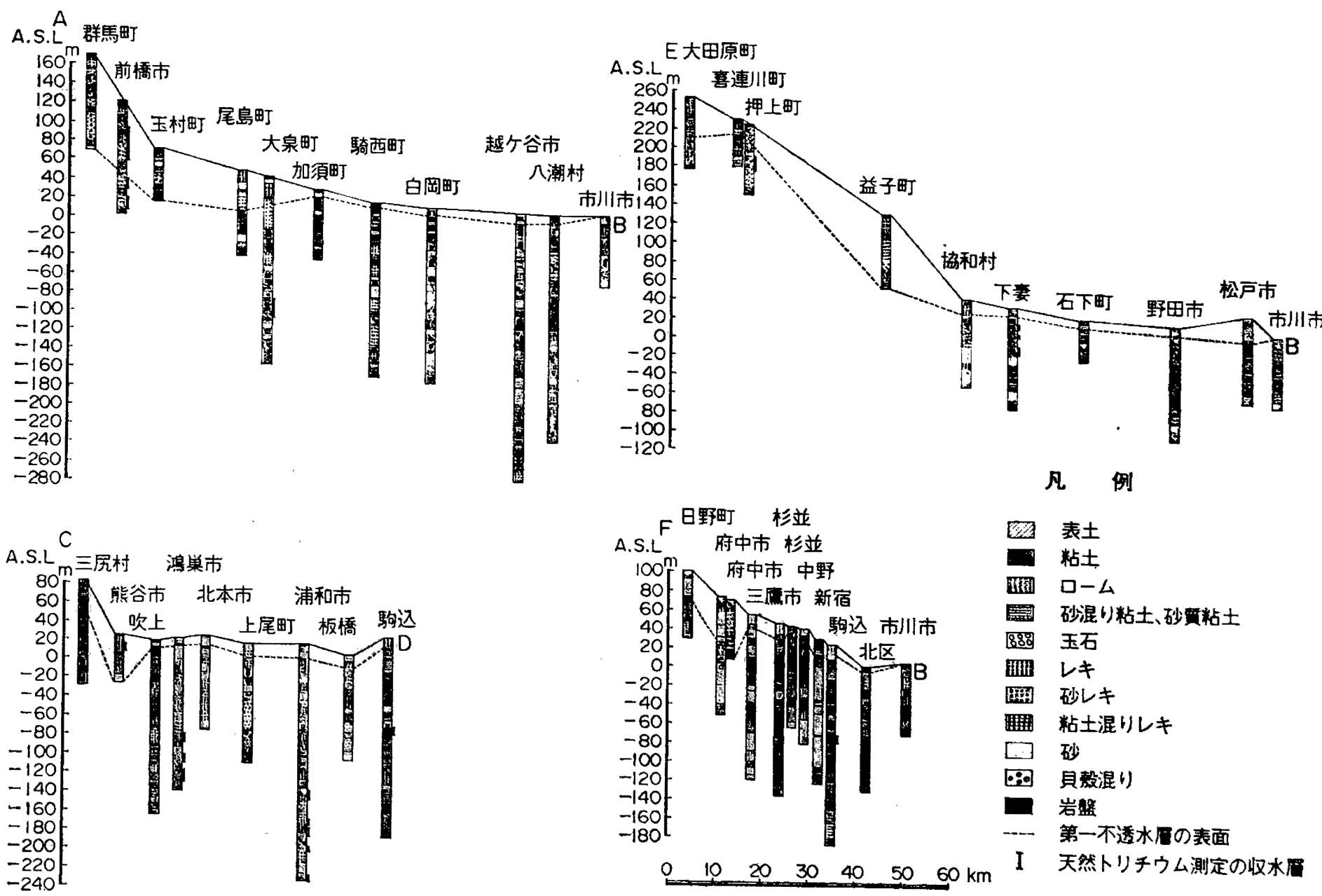


表 1 地下水の Tritium 浩度測定結果

\begin{tabular}{|c|c|c|c|c|c|c|c|c|c|c|c|c|c|c|}
\hline \multirow{3}{*}{ 地区名 } & \multirow{3}{*}{\multicolumn{2}{|c|}{ 地 }} & \multirow{3}{*}{ 層 } & \multicolumn{4}{|c|}{ 採 } & \multicolumn{3}{|c|}{ 年 } & \multicolumn{2}{|l|}{ 月 } & \multirow{3}{*}{ 所 有 者 } & \multirow{3}{*}{ 収水畨深度（m） } \\
\hline & & & & \multicolumn{4}{|c|}{1965 年 } & \multicolumn{4}{|c|}{1966 年 } & \begin{tabular}{|c|}
1967 \\
年 \\
\end{tabular} & & \\
\hline & & & & 3 月 & 4 月 & 5 月 & 9 月 & 2 月 & 3 月 & 8 月 & 9 月 & 2 月 & & \\
\hline 前 & & 沖 & & & & & & 90 & & & & 130 & 東 京 電 力 & $27 \sim 65,84 \sim 95,103 \sim 115$ \\
\hline 高 & & " & & 21 & & & & 3 & & 35 & & & 高 崎 製 系 & $48 \sim 67,97 \sim 116$ \\
\hline 高 & & & 積 & & & & & & & 18 & & & 沖電気 & $56 \sim 63,114 \sim 142$ \\
\hline 大 & & 沖 & & & & 42 & & & & 2 & & & 大泉町上永道 & $138 \sim 151,182 \sim 200$ \\
\hline 能 & & " & & & & & & 60 & & & & 369 & 熊谷市役所 & $44.5 \sim 50$ \\
\hline 境 & & " & & & & 62 & & & & 82 & & & ビワ砂水利組合 & $50 \sim 58,65 \sim 70,78 \sim 82$ \\
\hline 鸿 & & " & & & & & & & & & & 12 & 農 事試 験 場 & $99 \sim 111,126 \sim 132,139 \sim$ \\
\hline 浦 & & & 積 & & & & & & 3 & & & & 県南水道組合 & $\begin{array}{l}155 \sim 159,162 \sim 166,189 \\
\sim 190,192 \sim 206,216 \sim 222 \\
246 \sim 249,260 \sim 265\end{array}$ \\
\hline 土 & & & & & & 52 & & & & & 79 & & 東 京 電 気 & $50 \sim 58$ \\
\hline 東京・中里 & & 三浦～ & 層群 & & & & & & & & & 169 & 立成高校 & $60 \sim 68,76 \sim 102$ \\
\hline 小見 川 & & & 積 & & & 12 & & & & & 2 & & 富 士 工 業 & $79 \sim 89$ \\
\hline 押 & & $"$ & & & 354 & & 406 & & & & & & 鬼怒川学園 & $31 \sim 60$ \\
\hline 宇 都 宮 & & & 積 & & 101 & & 232 & & & 340 & & & パインミシン & $9 \sim 24,52 \sim 55,72 \sim 75$ \\
\hline 真岡 & & " & & & & 15 & & & & & 10 & & 仙波糖加工 & $30 \sim 35,39 \sim 44,49 \sim 56$ \\
\hline 小金 井 & & " & & & & 11 & & & & & 13 & & 日本麦 芽 & $47 \sim 53,55 \sim 64,68 \sim 77$ \\
\hline 妻 & & 沖 & 皟 & & & 347 & & & & 8 & & & 下妻市役所 & $42 \sim 51,58 \sim 61,89 \sim 97$ \\
\hline
\end{tabular}

はいずれも $10^{-2} \sim 10^{-3} \mathrm{~m} / \mathrm{sec}$ のオーダで大きい值を示している。さらに，図 2 の自由不透水盤深度 分布図によって，第一不透水盤までの深さが深く，降水はその上部の $k$ の大きい堆積層をそのまま垂 直的に浸透しているので, この第 1 带水層に設けられている収水層で Tritium 濃度が大きな值とな ったものと思われる。

また，これらの地帯は四８の地質断面図によって明らかなように，平野下流部の被圧地下水のかん 養地帯 (intake area) となっている。下流域に至ると第一層の不透水層は次第に浅くなり，広範な上 流地域でかん養された地下水流にいくにしたがって，次第に第一不透水層以下に入り，粘土と砂 レキ層の互層をなす哚層帯水層へ浸入して被圧地下水を形成している。

Tritium 測定の試料採取の収水層の位置は図 8 の地質断面に示したように中・下流域においては幾 層かの不透水層の下に存在する帯水層で, その地下水は上流のかん養地帯からかん養されたものと考 えられる。

中流域の大泉・境 (利根川水系), 宇都宮, 下妻 (鬼怒川水系), 鴻巣 (荒川水系) などでは, 12

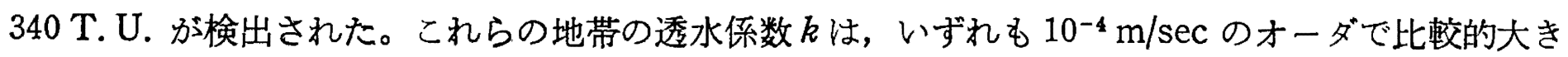
い地帯となっている。

したがって，この $k$ の大きい深層の帯水層の中を，1954年以降の水爆による T. U. 值の高い降水が 流動していることを示している。透水係数分布図にも示されているように, 関東中央部を占める大半 の区域においては $1 \sim 9 \times 10^{-4} \mathrm{~m} / \mathrm{sec}$ のオーダのるのが広く一様に分布し, 南関東は比較的透水性が 悪く相模原を除いては 10-•のオーダのところが多い。

これを地質的にみると，主として利根川，鬼怒川低地の沖積層に属する低平野では大部分 1〜9x 
(単位はT.U.)

\begin{tabular}{|c|c|c|}
\hline $\begin{array}{l}\text { 节井 } \\
\text { 年 度 }\end{array}$ & $\begin{array}{l}\text { 揚 水 量 } \\
\left(\mathrm{m}^{3} / \mathrm{sec}\right)\end{array}$ & $\begin{array}{c}\text { 透水係数 } \\
(\mathrm{m} / \mathrm{sec})\end{array}$ \\
\hline 1965 & 0.0318 & $1.7 \times 10^{-4}$ \\
\hline 1955 & 0.0472 & $3.5 \times 10^{-4}$ \\
\hline 1960 & 0.0313 & $6.2 \times 10^{-5}$ \\
\hline \multirow[t]{2}{*}{1967} & 0.0226 & \\
\hline & 0.0052 & $8.2 \times 10^{-4}$ \\
\hline 1949 & 0.0625 & $6.6 \times 10^{-4}$ \\
\hline \multirow[t]{3}{*}{1961} & 0.0247 & $3.0 \times 10^{4}$ \\
\hline & 0.0625 & $5.9 \times 10^{\sim 4}$ \\
\hline & 0.0063 & $6.4 \times 10^{\sim 4}$ \\
\hline \multicolumn{3}{|l|}{1967} \\
\hline \multirow[t]{2}{*}{1948} & 0.0084 & \\
\hline & 0.0104 & \\
\hline 1960 & 0.0083 & $1.2 \times 10^{\sim 5}$ \\
\hline \multirow[t]{2}{*}{1959} & 0.0185 & $4.8 \times 10^{-4}$ \\
\hline & 0.0417 & $3.2 \times 10^{4}$ \\
\hline
\end{tabular}

$10^{-4} \mathrm{~m} / \mathrm{sec}$ のオーダの透水係数 $k$ となり, その周辺の洪積台地において もほぼ等しい $k$ 值となった。（ただし，台地の表面を扇状堆積物がおお っている関東地方の西部・北部の台地群は例外である。）これはおそら く台地の地層が沖積層の下に連続しており，地下水も同様に連続してい るものとみられる。地質調査所がガス探査のため $3,000 \mathrm{~m}$ に及ぶ試錐を 沖積低地の埼玉県春日部で行ったが, 地表から $27 \mathrm{~m}$ まで沖積層, $424 \mathrm{~m}$ まで洪積層が存在していることが確認されている。また，河井興三7) に よれば関東平野中央部の古河付近で $100 \mathrm{~m}$ 以深, 栗橋と橴宮り間で $200 \mathrm{~m}$ 以深の地層が上総層群（成田層下部層）に属する可能性がきわめて大き いとされているので, 沖積層に存在する深井戸です主に洪積層の収水層 から採水していることになる。したがって，関東中央部の深層地下水は 同じオーダの $k$ となっている。山本荘毅8) あ関東各地では透水量釈数は ほぼ同じであると言っている。したがって, 関東中央部の地下水は, と くに特定の水脈にそって流動している状態でなく, ほぼ一様に上流から 下流へ流動しているものと推定される。水爆による Tritium 濃度の増 大值が地域的に一様な傾向に出たことはこれを裏付けるものである。

比較的低い T. U. 值を示したものは，小金井・真岡・鴻巣・小見川で 10〜15 T. U. を示した。真岡・小金井は鬼怒地下水系の両側に位置し, 押上で検出された 300 オーダの T. U. に比較すると非常に減少している。 荒川水系では上流の熊谷の 369 T. U. が中流の鴻巣で 12 T. U. となり, さらに下流側の浦和で 3 T. U. となっている。これは降水の Tritium 濃 度が水爆実験以後において, 図1で示したように指数的に増加しており, 被圧地下水のかん養带であ る上流地域に至るほど, 最近の Tritium 濃度の高い降水の浸透流動したものが現われて T. U. 值が 高く示され，中・下流域にいくにしたがってそれよりも水爆実験当初の古い年代の地下水が流動して いるので, T.U. 值が低く示されたものと思われる。

水爆実験当初の Tritium 濃度の低い降水によって地下水体を形成している front の T. U. 值は, 1954 年の降水の T. U. 值が約 20 T. U. と推定されるので咸衰を考虑すれば約 10 T. U. 前後になって いるはずである。

既に述べたように，水爆実験直前の宇宙線による天然トリチウム濃度は最大 5 T. U. 程度であるか ら，これらの值から両者の地下水体の境界を明瞭に区別することができるわけである。

したがってこのような見方から，水爆実験以後の地下水体とそれ以前の地下水体との境界は鴻巣と 浦和との間に存在することになる。

これに対し，東京都中野区富土見町の武蔵野台地東部の深井戸では，169 T. U. という高い值を検 出した。これは荒川・利根川水系と地下水系を異にし，この深井戸では鮮新世の三浦層群の砂層中の 地下水を採水しているので, この被圧地下水の地下水かん養帯の下流限は図 2 , 図 8 によって明らか なるように, 多摩川沿線の日野・府中あたりと考えられる。これは藤本”らの被圧地下水の形態およ び三浦層群の研究によっても裹付けられる。したがって，地下水の流動距離は約 $20 \mathrm{~km}$ 程度で, T.U. 值から1954年よりも比較的新しい年代の地下水であるといえよう。

これに対し, 山崎す らの測定による都内駒込の理化学研究所の深井戸地下水では, 最近に至っても 0.8 T. U. ないし 5 T. U. 以下で 1954 年以前の地下水となっている。 
これは鮮新世の三浦層群の表面地形が都内の南部から北部にかけて $1 / 50$ のウ配で 急傾斜してお $\eta^{10)}$ ，その基盤面は理化学研究所付近では海抜マイナス $100 \mathrm{~m}$ 以下となっているものと思われる。 Tritium 測定の採水深度はこれよりも浅く 65 90m であるので, 三浦層群の上部の洪積層（下部東 京層) から採水していることになる。

これらの結果から, 東京の西南台地の三浦層群中の深層地下水は, 東京層の地下水に比較して, 比 較的近い距離から地下水かん養を受けている。これに対し北東低地部の東京層中の地下水は荒川・利 根水系に属し, 遠距離から地下水かん養を受けており, 地下水の年代は数10年程度のあのとみなされ る。

以上のように上流域から下流域へいくにしたがって，地下水中の T. U. 值は次第に減少していく 傾向が認められたが，これは水爆実験による降水中の Tritium 濃度が指数的に増大していることか ら, 上流地帯から下流地帯と新しい年代の地下水加ら古い年代の地下水へと移行し，一連の連続的流 動機構を示しているものと推定される。

これらの結果から, 関東地方という大きい scale で被圧地下水のかん養機構を検討すると, 地表の 降水が直接的に帯水層とその上下にある賦圧層とを垂直的に浸透して収水層に達する時間よりも, 降 水が上流域の被圧地下水のかん養帯から浸入して, 帯水層にそって上流から下流へ水平方向に移動し て収水層に達する時間の方が早いことる示している。なんとならば，もし水平流動の方が遅いとする ならば，水爆による降水中の T. U. 值は関東という scale では地域的の変化は殆えど考えられない から，T.U. 值は同程度に出てくるはずである。したがって，関東水系全体として考えるならば，あ まねく地表面から垂直方向に降水が浸透して, 地下水をかん養するという要素よりも，帯水層のろ頭 から降水・河川によって地下水がかん養される要素の方が大きいと結論づけられる。

この結論は関東構造盆地の被圧地下水といかに人工的はかん養強化するかという問題を検討する場 合に重要となろう。

\section{Tritium 測定による被圧地下水の流動機構について}

地下水の Tritium の年代測定から，1954 年以前と以後の地下水体の境界線を描くことができる。 この境界線が明確に確認できたのは, 荒川水系のみであるが, 他の水系において $10 \mathrm{~T}$. U. 前後の才

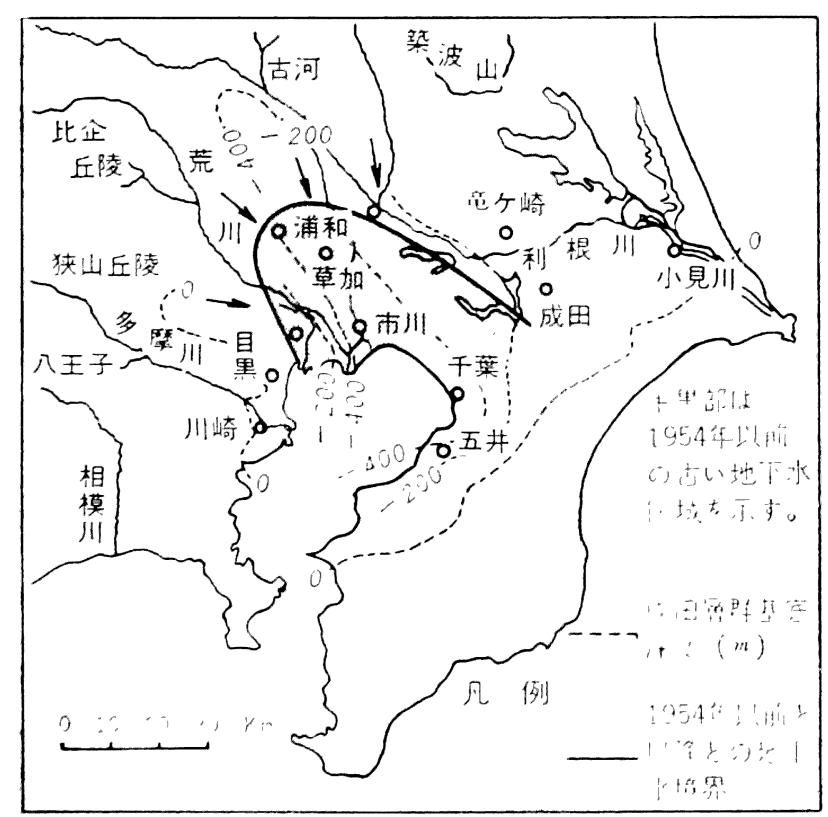

図 9 1954年以前以後の地下水体境界線図 一ダの1954 年以降に属する地下水体の front に近い と判定されたところが数か所あるので，これらの結 果を総括して1954年出前・以後の地下水体の境界線 を求めると図 9 に示したようになる。

この境界線の形は, 河井興三7)が作成した成田層 群基底の谷部の形とよく似ている。

この谷部は成田層群堆積時における沈降・堆積の 中心で盆状構造をなしており，その周辺部には図 2 に示したように，第一層の不透水層が深く，帯水層 の露頭を形成しているところが多い。これが被圧地 下水のかん養源地带を形成し，ここに浸透した降水 は地下水となり, 成田層群の傾斜方向, 寸なわち盆 状構造の中心部へ向ってほぼ一様に流動しているこ とが Tritium の測定によって明らかとなった。藤 本治義 ${ }^{11)}$ にればその中心部は加須付近とされているが，河井興三は最近の多くのガス井の地質を基 
にして，図 9 に示すように市川付近としている。Tritium の測定結果からもその中心は市川付近と推

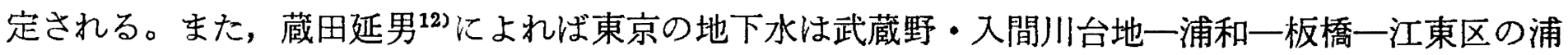
和水脈によって説明されているが, Tritiumの測定結果からは浦和水脈と限定することは無理のよう である。

1954年の地下水体の境界線と, 被圧地下水のかん養地帯の下流限とがわかれば, かん養地下水の平 均流動速度を算出することができる。

被王地下水かん養帯の下流限について検討すると, 図 8 の地質断面図および文献から, 利根川水系 では尾島付近，鬼怒川水系では杤木市南部一真岡13)，荒川水系では熊谷付近となる。これらの地帯よ り少し下流側に至ると，急激に第一不透水層は浅くなり，その上部の不珐水とその下部の被圧地下水 とに分かれ，大部分の地下水は被圧地下水へと移行している。

そして, 利根・鬼怒川水系には移行した下流側に妻沼・羽生・騎西および下館周辺の自噴井地帯が 存在する。

これらの関係は図 2 の不透水盤深度図からも読みとれる。

また，山本荘毅14)によれば，現在の荒川にそう地下谷は利根川につづいており，熊谷では荒川の伏 流水と利根川系統の複合であると指摘されているので, 荒川水系の地下水のかて養地帯の上流地帯に は利根川を考える必要がある。

これらの地下水かん養地帯の下限から上記の1954年以前・以降の地下水の境界線までの浸透距離を 求めると，利根川水系では $40 \mathrm{~km}$, 鬼怒川水系で $48 \mathrm{~km}$ となる。

1954年の水爆実験から新・旧地下水体のラインを求めた1967年 2 月までの期間は，12年となるから， それぞれの地下水系の平均流速は

$$
\begin{aligned}
& \text { 利根川水米 } v=\frac{40 \mathrm{~km}}{12 \text { year }}=9 \mathrm{~m} / \text { day } \\
& \text { 鬼怒川水米 } v=\frac{48 \mathrm{~km}}{12 \text { year }}=11 \mathrm{~m} / \text { day }
\end{aligned}
$$

となる。

利根・鬼怒水米の地下水か九養帯（自由地下水）でラジオアイソトープ ( $\mathrm{Na}^{131} \mathrm{I}$ ) を用いて，多井 追跡法によって実測した自由地下水の地下水流速は, 利根上流帯の鏑川 ${ }^{15)}$-16) で $40 \mathrm{~m} / \mathrm{day}$, 鬼怒川上

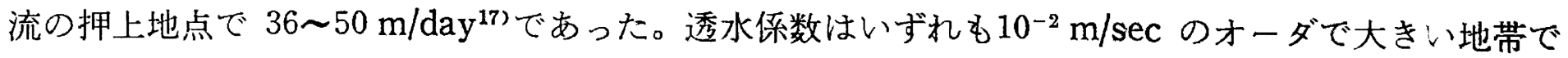
ある。これらの地帯の地下水は下流部の被圧地下水のかん養源となっている。

したがって，これより下流地帯の被圧地下水帯の地下水流動速度は, 地下水かん養帯の $1 / 4$ 1 $/ 5$ とな っている。

以上のように，Tritiumの年代測定から，関東地方の被圧地下水の流動機構が明うかとなったが, これらの結果には人工的揚水影響の要素を考慮しなければならない。

東京駅を中心として半径 $18 \mathrm{~km}$ （浦田・武蔵野・草加・船橋にかこまれた半円）の面積において， 深井戸の総揚水量を深井戸資料によって積算してみると， 266 万 $\mathrm{m}^{3} / \mathrm{day}$ となった。この小面積の揚水 量は東京を除いた関東の深井戸総揚水量 199 万 $\mathrm{m}^{3}$ よりも大きいことに注目すべきであろう。

したがって, その異常的な被圧水頭の低下は関東の構造盆地という地質構造の外に, この要素が地 下水の流動に大きな影響を与えていることは容易に推察できるところである。

したかって, 現存している1954年以前の古い地下水も近い将来において，市川方向に縮少され消滅 することが予想される。 


\section{5. むすび}

1. 関東平野というような大きな Scale の地下水流動機構を直接究明するような方法がなかったが, 地下水の Tritium の濃度測定から地下水の年代が決定され，これから地下水のかん養機構を究明す ることができることを明らかにした。

2. 関東における地下水の流動機構は，関東構造盆地と密接な関係があり，成田層基底の谷部に向 って利根・荒川・鬼怒川などの各水米の地下水が流動しており，1954年以降に浸透したトリチウム濃 度の高い地下水は, 現在, 市川を中心点とし鴻巣一浦和の中間を半径とした半円状に到達しているこ とが明らかとなった。

3. 従来, 被圧地下水の動きは殆んどないといわれていたが, Tritium の測定から関東中央部の被 圧地下水の平均流動速度を求めると, 利根水系においては $9 \mathrm{~m} / \mathrm{day}$, 鬼怒川水米で $11 \mathrm{~m} / \mathrm{day}$ となっ た。

これは関東平野の深層地下水の開発・利用の計画を樹立する場合に役立つであろう。

4. 関東平野の被圧帯水層に沶いては, Tritium 濃度の測定から, 降水の地表からの垂直的かん養 速度より，上流域の地下水かん養地帯からの水平的方向の帯水層によるかん養速度の方が速いという ことが明らかにされた。

このことは関東平野の深層地下水を人工的にかん養強化する方策を樹立する上に参考になるものと 思われる。 $(1968 ・ 1)$

\section{文献}

1) Begeman, F., W. F. Libby (1957): Continental waterbalance, Ground water inventory and storage time, surface mixing rates, and world-wide water circulation patterns from cosmic-ray and bomb tritium, Geochim. et Cosmochim. Acta, 12, p. 177-296

2) W.F. Libby (1953): The Potential usefulness of natural tritium, Proc. Nat. Acad. Sci., 39, p. $245-247$

3) W.F. Libby (1962): Tritium geophysics; Recent data and results, Tritium in the physical and biological science, (I.), IAEA, p. 6-29

4) E. E. Haskell, JR (1966): The use of tritium to measure the movement of ground water toward irrigation wells in Western Fresns County, California Tournal of Geophysical Research Vol. 71: No. 16 , p. $3849-3859$

5) 山崎 ・浜田・高橋 (1966): Progress Report (386/RB), IAEA

6）浜田・高橋・西田 (1967)：天然トリチゥム測定法の改良と水理学への二・三の応用, 第 7 回日本アィ ソトープ会議報文集，日本原子力産業会議，p. 117-119

7）河井興三 (1961)：南関東ガス田地带についての鉱床地質学研究, 石油技術協会誌, Vol. 26, No. 5, p. $1 \sim 55$

8）山本荘毅（1963）：関東地方の地下水について 一深層被压水を中心に一，全国地下水深井戸資料台帳 「関東編・上巻」p. $5 \sim 14$

9）藤本治義・新藤静夫 (1965)：武蔵野台地の水理地質（1）東洋大学工学部研究報告, No. 1, p. 51-82

10）東京都土木技術研究所（1963）：東京都地質眓集

11） 藤本治義（1951）：関東地方・日本地方地質誌，朝倉書店，p. 278-279

12）蔵田延勇（1967）：東京の地下水一五つの設問をめぐって一，工業用水，No. 107，p. 28-33

13）鈴木陽雄 (1964)：栃木県水理地質図説明書, p. 2, 杤木県企画調整室

14）山本㽵敦 (1959)：関東地方の自由地下水面, 地学雑誌, Vol. 68 , No. 4, p. 1-12 
15）落合敏郎 (1964)：トレーサーによる地下水の調査, 原子力工業, Vol. 10, No. 12

16）落合ほか (1965)： ラシオアイントープによる地下水追跡に関する研究（I）農土試報告, No. 3

17）落合敏郎 (1966)：鬼怒川上流城の地下水包蔵量について 一とくに原子力による調查結果を重点とし て一, 用水と廃水, Vol. 8 , No. 9, p. $11-22$

日 本地質学会 75 周 年記念出版

\section{日本の地質学}

本書は，75年にわたる日本地質学会の歴史に見られる主要な発展期を回顧し，各分野の現状 を分析するとともに，将来の地球科学の体系における地質学の位置とその役割を展望する。

執筆は。すでに大きな業績をあげて一派の学風を完成された既成の大家をさけ，現在具体的 な問題にとり組えでいる中堅研究者に依頼した。

全文は，約 600 ページで， 3 部に分かれる。

希望者は, 日本地質学会（東京都文京区本郷 7-3-1, 東京大学理学部地質学教室）まで 申込。1 部, 3000円（送料別, 約 150 円）

\section{(主要目次)}

第 I 部 特別寄稿

第II 部 日本地質学の展望

第部 日本地質学界の展望 